\title{
Voicing up in Debate Competition: Oral Development of Two Malaysian ESL Learners
}

\author{
Farzaneh Amiri ${ }^{1}$, Moomala Othman ${ }^{1} \&$ Maryam Jahedi ${ }^{1}$ \\ 1 Department of Language and Humanities Education, Faculty of Educational Studies, Universiti Putra Malaysia, \\ Serdang, Selangor, Malaysia \\ Correspondence: Maryam Jahedi, Department of Language and Humanities Education, Faculty of Educational \\ Studies, Universiti Putra Malaysia, 43400, Serdang, Selangor, Malaysia. E-mail: jahedi73@gmail.com
}

Received: August 14, 2016

doi:10.5539/ass.v12n12p90

\author{
Accepted: September 5, 2016 \\ Online Published: October 29, 2016 \\ URL: http://dx.doi.org/10.5539/ass.v12n12p90
}

\begin{abstract}
This research used a qualitative approach to focus on the classroom debate between Malaysian English second language learners (ESL). Since debate has been often perceived as not a suitable activity for low proficiency students due to their limited linguistic resources, there has not been much emphasis on the impact of debate on incompetent ESL learners; however, this study was an attempt to concentrate on two students who were not competent in English to investigate their oral development via debate. The study observed the communicative strategies employed in this challenging task during the five debate rounds. Although the progress made was quite limited, the study showed that debate competition can be a relevant and meaningful practice for speaking activity among low proficiency students. Moreover, it showed that debate can be used to scaffold students' practice in speaking.
\end{abstract}

Keywords: debate, second language learners, speaking skills

\section{Introduction}

Communicative competence is the ability of an individual to use a language effectively in an actual communicative situation (Hymes, 1972). To interact successfully, the individuals need to know the structure of the language and how to use it effectively within a social context. For ESL learners, it is not enough to possess only the linguistic knowledge of the target language. They must also know the sociolinguistic rules and conversational norms in order to participate effectively in a discourse community (Canale \& Swain, 1980). Studies have shown that exposure to the target language makes the learners more effective in language production and interaction (Freiermuth \& Jarrel, 2006; Phillip, 1992). Thus, it is important that learners be exposed to formal and informal, dyad, group and classroom contextual settings and various discourses to facilitate the language learning process (MacIntyre, Baker, Clément, \& Donovan, 2003).

Similarly, it is suitable to introduce debate to students as it involves multiple contextual settings: formal and informal as well as dyad and group. Debate can scaffold learners to express their opinion by incorporating comprehensible input and output (Othman, Mohamad, \& Amiri, 2013). This is possible as debate is a structured discourse that allows learners to take up various roles and develop basic interactive skills. In the process, students will learn the ability to initiate and maintain a conversation and express an opinion, while speaking skills are often noted to be lacking among ESL learners (Brice, 1992).

Debate is often shunned by beginner and intermediate ESL learners as it is perceived as an activity suitable only for proficient learners. However, this study focused specifically on using debate in developing speaking skills of students with lower English proficiency level. Therefore, two Malaysian ESL learners in a boarding school were selected for the study; a boy with poor English proficiency level and a girl who was an intermediate proficiency learner. No doubt the research acknowledges the limitation with two samples, but it helped to gain understanding of the experience these students underwent as participants during debate competition phenomenon.

\section{Literature Review}

Speaking is an essential and important skill that an ESL learner needs to learn in order to communicate effectively in real-life situation. And yet this is often the skill neglected in ESL language classroom (Goh, 2014; Thornbury, 2005; Ur, 1996). Traditional classroom which is teacher-centered does not help learners to develop 
their speaking competence (Brown \& Yule, 1983; Henzl, 1979). Of all the four skills taught, ESL learners, particularly the intermediate and beginner students, find speaking the most challenging (Goh, 2014) since it involves spontaneous interaction; the learner has to comprehend what is said before coming with the right response. At the same time, the learner must not take a long time to reply or the listener would lose interest. Thus, herein lies the challenge with speaking which involves the interplay of social, cognitive, as well as affective factors (Goh, 2012). Therefore, it is imperative that the learning process involving speaking occurs in an active, strategic and constructive environment (Bruer, 1998).

To achieve the above, it is important that the speaking activities be student-centered and collaborative in nature (Goh, 2014; Weimer, 2013). Teachers must provide authentic, meaningful and relevant communicative activities (Harmer, 2001). Some of the scaffolding suggestions focus on promoting accuracy among learners. Thornbury (2005) suggested that learners need to notice the language usage before carrying the activities. This will create their awareness of the language structures (vocabulary, grammar and pronunciation) which facilitate language learning when learners use them in their practice. Learners also need to be provided with the spoken text to help them learn the structure involved in a particular discourse thus leading to development of a more effective discourse skill (Burns, Joyce, \& Gollin, 1990). Skehan (1996) suggested that the activities must be specially planned (task-based learning) to ensure that the target language is used for a purpose and served a communication goal or outcome. Bygate (2001), on the other hand, suggested spontaneous speaking and repetitions to promote fluency over accuracy and to develop leaners' confidence and motivations. Although the previous studies have shown that setting and relevant scaffolding are paramount in order to achieve learning goals, there is controversy whether to emphasize accuracy over fluency and vice versa.

Another suggestion is the need to inform ESL learners about communicative strategies (Færch \& Kasper, 1983). Communicative strategies are those strategies that learners use to facilitate interaction by ensuring that there is no breakdown in communication. Oxford (1990) refers to strategies as "specific actions taken by the learner to make learning easier, faster, more enjoyable, more self-directed, more effective and more transferable to new situations" (p. 8). In addition, O'Malley and Chamot (1990) view learning strategies as "the thoughts and behaviours that learners use to help comprehend, learn, or retain information" (p. 43). Speaking involves accuracy and fluency (Harmer, 2001). It is challenging for a beginner to hold a conversation fluently without making any mistakes. Too often, when ESL learners communicate, they focus on the message and are not aware of the errors. In this aspect, many educators believe that it is not necessary to force students to communicate accurately since keeping a conversation alive is itself challenging (Nolasco, 1987). According to Færch and Kasper (ibid.), ESL learners often use "avoidance strategies" such as abandoning a conversation half way when it gets too difficult or pretending not to hear or understand. This is in contrast to "compensation strategy" (Oxford, ibid.) where the learners use their limited language resources for production. For example, they resort to their mother tongue, paraphrase, and appeal for help from others or use readymade phases, termed chunking. Though some have suggested that teaching of communicative strategies should be explicit, there are others who believe that communicative strategies are part of language development that learners will pick as they learn the language. The more successful their language learning and contact is, the more communicative strategies will be employed (Tarone, 1980). Therefore, the oral development of learners can be identified by studying the communicative strategies that they employ.

Thus, to facilitate the learning process in the speaking activity, it is important that the above suggestions be taken into account. In carrying this study, these considerations were incorporated throughout the debate activity to assist the learners. It was aimed to find the development of low and intermediate proficiency students' speaking skills through debate and to identify the communicative strategies employed using debate. Therefore, the study tried to answer the following questions:

1. How do Malaysian ESL learners with low and intermediate English Proficiency levels may improve their speaking skills through debate?

2. What are the communicative strategies used by Malaysian ESL learners using debate?

\section{Method}

In this research a case study approach was adopted. "Case study research involves the study of an issue explored through one or more cases within a bounded system such as a setting or context" (Creswell, 2007, p. 73). The research comprises qualitative data obtained through direct observation, video tape recordings, transcripts of students' debate presentation and interviews with students. These qualitative explorations provided rich input on how these two ESL learners approached debate and how they perceived it which allowed us to understand the uniqueness of their situation in that specific context and interaction (Patton, 1985). 


\subsection{Data Collection Procedure}

There were four stages involved in this study, including (1) pre-debate; (2) debate workshop; (3) mock debate; and, (4) debate competition.

\subsubsection{Pre-Debate}

A test comprising 50 Multi Choice Question items was conducted two weeks before the debate session. The test aimed to determine the proficiency level of the students and the subjects were chosen based on the raw score obtained. Then two students with lower proficiency level were selected; one boy whose score fell within the weak band and one girl with average or intermediate proficiency level.

\subsubsection{Debate Workshop}

There were 120 students divided into groups of 12 and were subsequently sent into 10 classes. For each class, three trainee teachers were assigned to give explanations about debate, its structure and roles of each speaker. The students were provided with a debate script format for different speakers. This script was actually a spoken text of a debate but with gaps that students needed to complete. The students in each class were seated in a debate seating position as presented in Figure 1 below. This assisted in the explanation about debate as a discourse to the students.

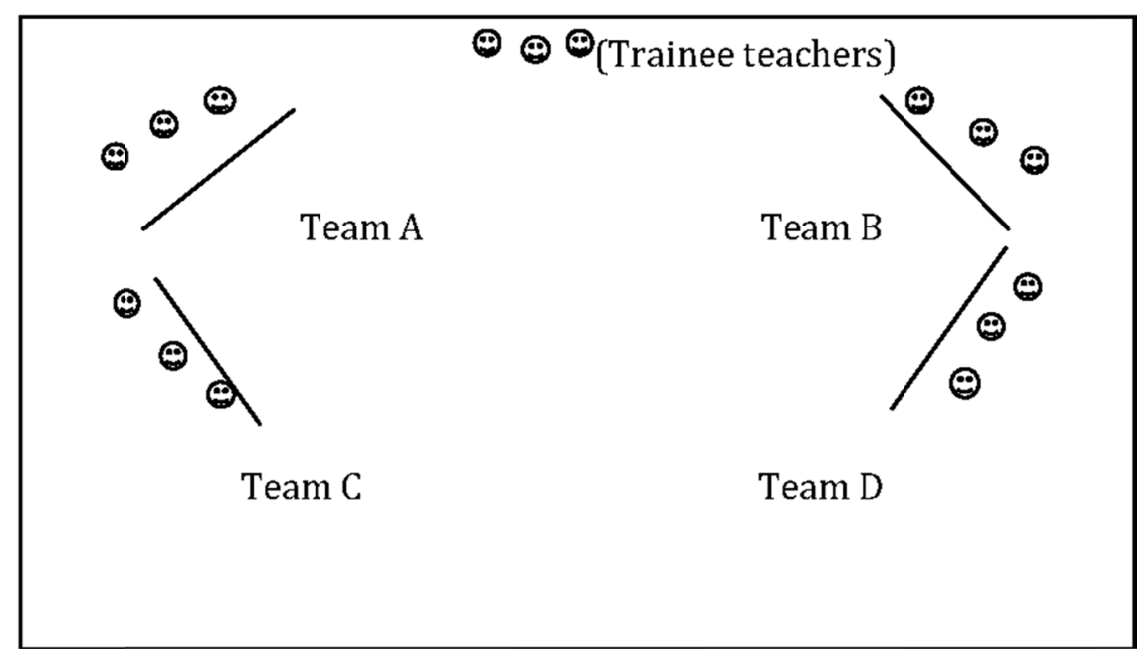

Figure 1. Debate seating position

The students were further divided into two groups: the opposition and the proposition group. Those on the right were the proposition while those on the left were the opposition. A summary of the role of each speaker is presented in Table 1 below:

Table 1. Speakers' roles in debate

\begin{tabular}{|c|c|}
\hline Proposition & Opposition \\
\hline $1^{\text {st }}$ speaker: & $1^{\text {st }}$ speaker: \\
\hline $\begin{array}{l}\text { Proposes the motion, states team's stand and } \\
\text { claim, offers POI when opponents deliver the } \\
\text { speech. }\end{array}$ & $\begin{array}{l}\text { Opposes the motion, rebuts the claim by } 1^{\text {st }} \text { proposition } \\
\text { speaker, states the team's stand and claim, offers POI } \\
\text { when other opponent delivers the speech }\end{array}$ \\
\hline $2^{\text {nd }}$ speaker: & $2^{\text {nd }}$ speaker: \\
\hline $\begin{array}{l}\text { Rebuts opponent's } 1^{\text {st }} \text { claim, reaffirms the stand, } \\
\text { states Proposition } 2^{\text {nd }} \text { claim, accepting/ offering } \\
\text { POIs }\end{array}$ & $\begin{array}{l}\text { Rebuts claims by proponent's } 2^{\text {nd }} \text { and } 1^{\text {st }} \text { speaker, } \\
\text { reaffirms the stand again, states opposition } 2^{\text {nd }} \text { claim, } \\
\text { accepting/offering POIs }\end{array}$ \\
\hline $3^{\text {rd }}$ speaker: & $3^{\text {rd }}$ speaker: \\
\hline Rebuts Opposition $2^{\text {nd }}$ Speaker claim, reaffirms & Rebuts Proposition $2^{\text {nd }}$ Speaker claim, reaffirms the stand, \\
\hline
\end{tabular}


the stand, states Proposition $3^{\text {rd }}$ claim (it could be a new point or an extension of the point made by speaker one or two), accepting or offering POIs

$4^{\text {th }}$ speaker:

Rebuts Opposition $3^{\text {nd }}$ Speaker claim, reaffirms the stand, states Proposition 4th claim (it could be a new point or an extension of the point made by speaker one or two), accepting or offering POIs

$5^{\text {th }}$ speaker: Whip

Rebuts all claims beginning with the most recent- $4^{\text {th }}, 3^{\text {rd }}, 2^{\text {nd }}$ and $1^{\text {st }}$

$6^{\text {th }}$ speaker: Closure

Summarizes all opponents' claims, and explaining why it is unacceptable, stating the gist of the proposition claims, why the proposition argument is better. Reaffirms the proposition stand. state Opposition $3^{\text {rd }}$ claim (it could be a new point or an extension of the point made by speaker one or two), accepting or offering POIs

$4^{\text {th }}$ speaker:

Rebuts Proposition $4^{\text {th }}$ Speaker claim, reaffirms the stand, state Opposition 4th claim (it could be a new point or an extension of the point made by speaker one or two), accepting or offering POIs

$5^{\text {th }}$ speaker: Whip

Rebuts all claims beginning with the most recent- $4^{\text {th }}, 3^{\text {rd }}$, $2^{\text {nd }}$ and $1^{\text {st }}$ $6^{\text {th }}$ speaker: Closure

Summarizes all proponents' claims, and explaining why it is unacceptable, stating the gist of the opposition claims, why the proposition argument is better. Reaffirms the opposition stand.

Another feature of the debate is the use of point of information, POI, which is a request by any member of the rival team to the speaker who holds the floor to allow some of his or her time for a query made on any matters presented by the speaker (Edward, 2008). Demonstration on how to use POI was shown to the students i.e. by extending one's hand or rising and saying, "Point of information".

\subsubsection{Mock Debate}

Immediately after the workshop students debated on a topic entitled, "Spider Man is better than Iron Man". This was the mock debate. It was all hands-on experience aimed to familiarize the students with debate. When students were ready to start, the teacher trainees became judges. General comments and feedback were given at the end of the debate.

\subsubsection{Debate Rounds}

Students debated four times. As in the mock debate, students were given 15 minutes to brainstorm before each round and the teacher trainees would help the learners in the discussion. After each debate round, feedback on grammar and pronunciation and how to improve their delivery were provided and winners were announced. The debate took place during the weekend as part of a co-curricular activity. Round 1 and round 2 were held on Saturday while round 3 and round 4 were held on Sunday. The motions were:

Round 1: KFC is better than the McDonald's

Round 2: Girls talk more than boys

Round 3: Batman should remove his mask

Round 4: Western cartoons are better than Japanese cartoons

\section{Results}

The following section looks at the observation notes, video recordings and students' transcribed speeches at each stage of the debate competition. Speeches which were based on the prepared script are underlined while those parts not underlined are speeches composed by the students themselves.

\subsection{Comparison of Low and Intermediate English Proficiency Learners during Four Debate Rounds}

\subsubsection{Mock Debate: Spider Man Is Better than the Iron Man}

During this stage both subjects were seen as text dependent. Basically, they were reading from the text they had prepared. Both had difficulty in replying rebuttals. Description of what was observed is described accordingly.

I. Participant with Low English Proficiency Level in Mock Debate 
The subject had the most difficult role as the whip. This role required him to rebut all points given by the three opponents. He started his reply speech by reading the introduction of the debate script. The reading of his prepared text was difficult. He was shy (sheepish) and very uncomfortable. His pronunciation was bad and his reading was not clear. When he was giving his rebuttals, he chose the avoidance strategy (Færch \& Kasper, 1983); he could not come up with a reason to counter. He looked at the camera a few seconds, covered his mouth with his script and then abandoned his speech by concluding straight away. No rebuttal was delivered. During the entire session, there was no eye contact with the opponents. His speech lasted for one minute and twenty seconds. He lacked confidence. Overall, his reading was difficult and incomprehensible due to bad pronunciation and poor intonation. For his oral assessment, he obtained band $\mathrm{E}$ with a score 2/20.

\section{Participant with Intermediate English Proficiency Level in Mock Debate}

The subject was the fourth speaker. Her role was to rebut points raised by the earlier opponent followed by her introduction of a point and its elaborations. The subject delivered her speech by reading closely her prepared speech. Some words were mispronounced. She could not give a reason to rebut the opponent's argument:

\section{You said (looking down) Iron man depend on his suit but I disagree because .... (Pause)}

The student paused, looked down at her written text, bit her lip, and looked sideways for help from her friends. The teacher then urged her to continue with the next line. Student stood still. Again the teacher asked her to continue. Then, she read her text by stating her point and its elaborations. In delivering her speech, the student was observed reading closely her text. There was no eye contact except when the facilitator interrupted her speech to ask if she would accept the POI. This occurred twice and she responded with a short turn, "Deny". Overall, her reading was clearer and better than the other subject. Her speech lasted 2 minutes and 02 seconds. In comparison, this student was more confident. For her oral assessment she was given band D with a score 10/20.

\subsubsection{Debate Round I: KFC Is Better than the McDonald's}

During this stage two additional features observed in both subjects were (1) Replying Rebuttals and (2) Denying POI. Further descriptions of each subject's performance at this stage is as follows:

\section{Participant with Low English Proficiency Level in Debate Round 1}

During this stage, the low proficiency participant was delegated the fourth speaker who was less demanding than the previous role. For this role (fourth speaker), the subject was supposed to rebut the previous remarks mentioned by the opposition first speaker and make a firm response in defending his group's stand. He was able to do so this time. His speech was soft. His posture of not standing straight perhaps affected his speech. The facilitator interrupted him to speak louder. Despite this, he did not have clear pronunciation of some words. Some parts of his reply speech were incomprehensible. His hesitant speech and intonation interfered with the message. His speech had elaborations as he used words like "because" and "example", but since his overall delivery was still poor, it was difficult to decipher his argument:

You said KFC has ... (?)... but I disagree because ... (?)...I KFC. As mentioned by my teammates I agree with todays' motion because KFC has... (?)...but not ... (?) There are many ... (?)... Interesting ... (?)... for example ... (?)... And more...

As expected he did not demonstrate much confidence while delivering his speech. There was an interruption and he used his head gestures which meant "what". An opponent then stated, "POI". His response was not clear. Obviously, it meant, "Deny" for he then hastily continued with his speech:

With that I would like to say KFC ... (?)...

For the oral assessment he was given band $\mathrm{E}$ with a score $4 / 20$. His speech lasted for two minutes and twenty six seconds. It was longer than the first attempt.

\section{Participant with Intermediate English Proficiency Level in Debate Round 1}

For this round, the subject did better in her role as the whip. She could reply the rebuttals and elaborate each argument. She read her prepared speech from the text which was placed on the table.

First, you said, KFC only sells chicken but MCD have beef and fish. I think KFC also have burger, coleslaw and rice sale. [Paused to look at judges].Next, you said, KFC is famous in Malaysia but not in other country. But this is Malaysia, we are in Malaysia now. Next, you said KFC have high cholesterol but MCD burger use the same... [Interruption from judges: accept POI?] Deny.

Despite this, she was dependent on the text; she had a brief eye contact when the judge interrupted her speech for the POI. She refused to accept the POI and continued reading her reply speech. 
So in conclusion, I would like to say, we, the Government firmly agree with the motion that KFC is better than $M C D$.

Overall, her intonation was good and her reading was fluent. There was no hesitation in her speech. Despite the improvement in her language production, the oral assessment she obtained was in the band of $\mathrm{D}$ with a score of $12 / 20$.

\subsubsection{Debate Round 2: Girls Talk More than Boys}

During this round, the subjects remained in the same role; the girl (average proficiency) was the whip - fifth speaker while the boy was the fourth speaker. A feature of this stage is Denying POIs. Details of observation of both subjects are described below:

\section{Participant with Low English Proficiency Level in Debate Round 2}

This time the subject seemed more confident when he repeated the introduction part of the debate script. Unlike the first two attempts, this time he seemed very composed and his delivery had good pacing when he repeated the lines. He had gestures, good eye contact and was standing erect. His speech was clearer and more persuasive compared to the previous ones:

\section{A very good morning to the chairperson, honorable adjudicators, precise timekeeper, members of the opposition team, my fellow teammates and members of the floor. The motion of today's debate is girls talk more than boys.}

Obviously, debating for two rounds and observing and listening to his peers' response had its benefits. He picked out some useful gestures (hand and eye contact), and during the introduction, his speech had better pacing and his pronunciation was clearer. However, after the introduction part, his speech was less clear - he swallowed some of the words used. This was the part where he tried to use his own words to present his arguments and rebuttals:

Girls talk more than boys? We the? government team agree with the motion. Before, before, before I give my point. You said, you said boy brave to talk but I disagree because the? girl is brave to talk? too. As mentioned by my teammates, I agree with today's motion? Girls? Like a boy. Example at the assembly Sek Men...... girl talk more than boy because girl not shy to talk compared boy. O with that I would like to say again...

Again his intonation affected his message. He then stopped his speech when he received a POI from the opposition group but he was not willing to accept it. Instead of stating the usual short turn "Deny", he kept repeating: Tak! Tak! Tak! Then, he looked down at his prepared text, and concluded:

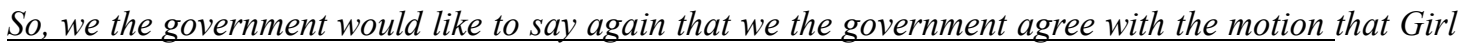
talk more than Boy! TQ.

An interesting observation here is that the subject did not articulate "Deny" when rejecting the POI, Instead, he articulated "Tak! Tak! Tak!" which is actually equivalent to "Not, Not, Not" in English language. This is an example of compensation strategy (Oxford, 1990) where the subject had resorted to his mother tongue to prevent breakdown of communication. Overall, the subject made progress in his speech, particularly at the delivery of his introductory speech and also he ended his speech exclaiming loudly, "Girl talk more than Boy!" For this round, the overall oral assessment he obtained was 7/20.

\section{Participant with Intermediate English Proficiency Level in Debate Round 2}

For this stage, the participant took the role as the fifth speaker, the whip of the opposition team. Her language command was fairly good as she could defend her rebuttals with elaborations. The production speech was comprehensible and fluent:

First you said, boys are more glamorous than girls but if you go to some universities you can see more girls there. Next, you say boys are leaders, but now girls are leaders too. Next you say boys are more brave than girl but now I think girls are more brave than boy, If you see girls at Sek. Men.... You see girls are more brave because they are not shy. Lastly, you say boys are friendly but girls are friendly too. So, in conclusion, I would like to say girls talk more than boys.

However, at times, she seemed cavalier and less enthusiastic in giving arguments. No POI was given during her time. For this round, the overall oral assessment was fair and the score given was 13/20.

\subsubsection{Debate Round 3: Batman Should Remove His Mask}

The third stage of debate was supposed to be a humor round. The facilitators often reminded participants that 
they were allowed to include funny remarks and opinions as well. However, it was seen that it was not easy for them to inject humor in their speeches. For this round, both subjects were given different roles. The girl (average proficiency) was given the role as the $1^{\text {st }}$ speaker of the opposition while the boy (poor proficiency) was the third speaker of the opposition.

I. Participant with Low English Proficiency Level in Debate Round 3

For this stage, he was given the role of the third speaker of the opposition. He was supposed to rebut the previous remarks made by the government and then present his argument. He delivered his speech by reading his prepared text. He repeated the usual introduction of the debate script. However, when he gave his rebuttal followed by his train of argument, some parts were incomprehensible and vague due to his intonation and pronunciation of certain words.

You said Batman should open his mask but I disagree because? his mask. As mentioned by my teammates, I think? motion Batman? face? he must wear the mask so with that we the opposition disagree with the motion

His delivery was also less effective because he seemed tired. Hence, no remarkable progress was found in his speech and unlike the second round he seemed more reserved in his presentation. For his oral assessment, he obtained a score of $6 / 20$.

\section{Participant with Intermediate English Proficiency Level in Debate Round 3}

Being the first speaker, the subject (the average student) was supposed to start her speech by giving her rebuttal:

You said Batman should remove his mask but I disagree because maybe if he rescuing people, his friends come to disturbing him.

This is followed by the definition and presentation of arguments:

Before I make my case as to why we agree with the motion, let me define key points. Batman is a man who save people who in danger. First reason why we disagree with the motion is that Batman should not remove his mask to protect his identity because maybe he is handsome or ugly? rescuing people. So...

Before she concluded she was interrupted with a POI. Unlike the previous speech, she was bold as she accepted the POI of the opponent:

I accept [What if Batman's friends can give support to him? TQ.]

She remained uncertain about what was heard. So the opponent responded:

[Do you hear what I say? Do you understand?]

Giggle/laugh [the opponent responded again: What if his friends can give him support instead of disturbing him]

Maybe... the... [Looked down at paper. Long pause and stood quite uncertain how to answer]

After a while, her friend nudged her to continue and complete the text. She then abandoned her attempt to answer the POI and continued with her speech which she ended quickly:

With that, we the opposition do not agree with the motion, batman should remove the mask."

Unlike the previous role, she had ample time to write out her speech while listening to others. Hence, her speech was short. Despite this, after delivering her rebuttal she acknowledged acceptance with a gesture. However, she was lost for words after replying, "maybe... the..." until her friend (next to her) nudged her to proceed with her argument. This was the only time during the debate competition the subject dared to accept the POI and attempted to be spontaneous, and not be dependent reading her prepared speech verbatim. For her oral assessment she obtained the score 13/20.

\subsubsection{Debate Round 4: Western Cartoons Are Better than Japanese Cartoons}

During this stage, both subjects were observed to gain assertiveness in delivery by incorporating non-verbal strategies. This was the last debate and everyone seemed excited to finish the tournament. This was palpable in the performance of both subjects; they both gave their best. Debate round four ended with the subjects remaining in the same position; the student with poor proficiency was the $4^{\text {th }}$ speaker of the opposition and the student with intermediate proficiency was the $5^{\text {th }}$ speaker or the whip of the opposition team. Details of the observation of both subjects are described accordingly: 


\section{Participant with Low English Proficiency Level in Debate Round 4}

During this stage, as the $4^{\text {th }}$ speaker, the subject was more composed and relaxed. His posture was better (stood straight), he had hand gestures and eye contact in his delivery. He read his text, but sometimes he referred to it while looking up at the audience. Pacing of his speech was good. His voice was louder. He provided examples and further elaboration to support his argument, but some words were not clear. Overall, he was much confident in this round and this was his best performance. For his oral assessment, he obtained a score of 9/20.

You said that Western Cartoon (WC) are not interesting, but I disagree because WC are more? than Japanese Cartoon (JC). For example, tree Max and? You have a unique and interesting project during their holiday. So with that I would like to say again WC are better than Japanese cartoon.

II. Participant with Intermediate English Proficiency Level in Debate Round 4

The subject was also much confident in this round. Her delivery and speech was the best in this competition. She was very confident and delivered her speech with much spirit. She was loud and her voice projection was good. There was good usage of hand gestures for emphasis effect (she hit the table). She read and referred to her text often as she would constantly look up at the audience. Her arguments were better elaborated; for each rebuttal she provided two claims. She also used one rhetorical questioning in her argument. No POI was given during this time. For her oral assessment, she obtained a score of 15/20.

First you said JC are famous but WC are more famous around the world such as Tom and Jerry, for example. If you ask the kid about $T \& J$, kids may be can answer it. Next, you said you can learn the Japanese language by watching the JC but if you watch the WC you can improve your English. People around the world use the English language as the international language. Next, you said Japanese C have more moral, but you did not give the example. How can you say that?

\subsection{Participants' Feedback on Debate Activities}

The subjects were interviewed twice; once immediately after the debate competition was over and the second time was six months after the competition. During the first interview, the subjects looked uncertain. The interview was brief; as it was obvious that both wanted to leave with the rest of the students. The girl did not say much. The boy kept referring to a piece of paper and repeated the same sentence, "debate is fun and interesting." He did not elaborate more. It was obvious that he was anxious and shy.

Six months after the debate competition, the second interview was conducted. Unlike the first time, both subjects were more composed and relaxed. The boy was still soft spoken, but less shy. Both replied that it was the first time they had debated and the most difficult part was initially the rebuttal. They said that group discussion was very important. They sought help from their peers by listening to their arguments. The discussion they had was in their mother tongue and not in English language. Both stated that they had no problem debating in English. The boy stated that he had difficulty to express the ideas or provide elaborations during the brainstorming session. The debate script provided was helpful. At the end of the interview they were asked if they would take part in debate again. The boy thought for a while and finally responded that he would; however, the girl gave a quick reply: she nodded no.

\section{Discussion}

This study showed that these two subjects underwent four stages before they finally gained some confidence. In the first two stages, they were uncertain in finding their way to familiarize themselves with the debate discourse. Hence, at these stages, initially both subjects lacked confidence and were reading from their verbatim written text. However, at stages three and four, they were referring to the text rather than reading it as they had internalized the repeated phases of the debate script. The verbatim text they had prepared ensured fluency in their delivery. Replying rebuttals and accepting POIs were two areas these two students found challenging. Collaborative learning and peers interaction were also important scaffolding elements; there was marked improvement in their nonverbal exchanges at later rounds. There were more gestures and eye contact with the opponent. There was also improvement in the content of their speech. They provided examples and some elaborations or explanations in their speeches at each round. Finally, they both were able to deliver their speeches with much confidence by incorporating the nonverbal aspect into their speeches. At the end of the activity, students realized the importance of nonverbal as well as verbal elements in sharing and conveying ideas (Chaney, 1998). As observed in their oral proficiency assessment, enormous improvements were made gradually from the initial mock debate till the final debate which can be seen in the following Figure: 


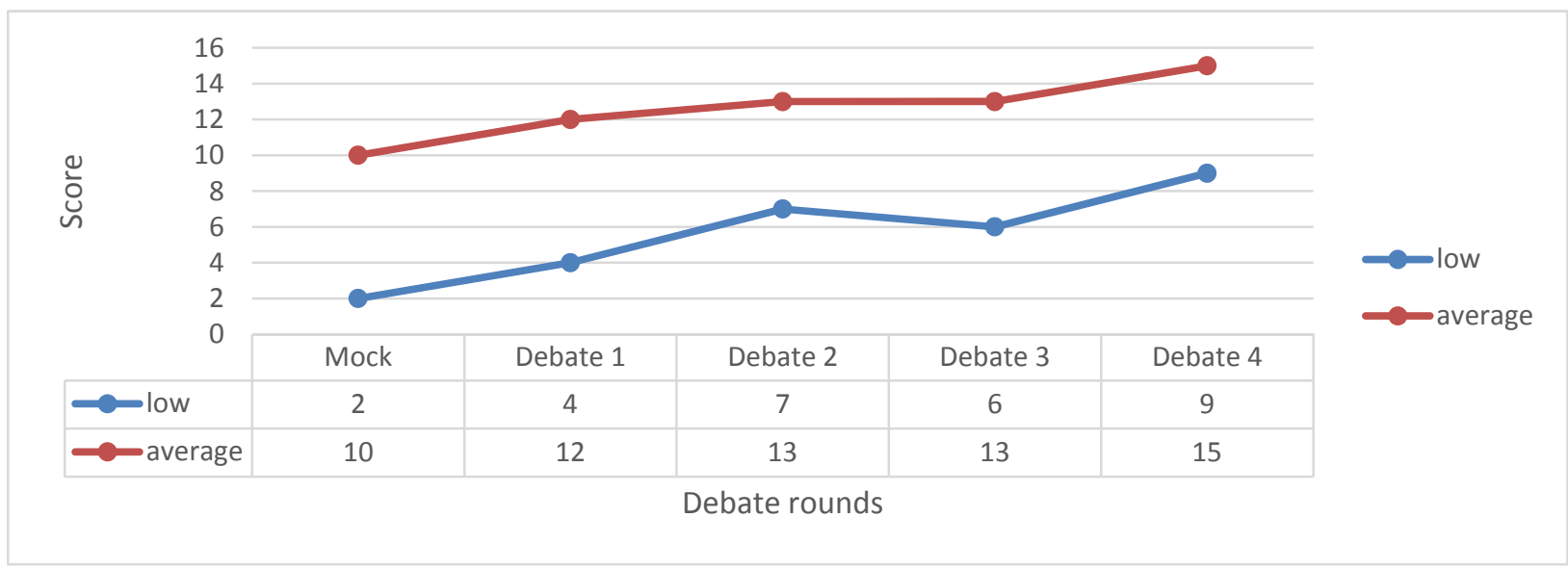

Figure 2. Oral assessment of low and intermediate english proficiency students during debate competition

The study also revealed that, there were two parts of debate which require different skills for these learners including (1) the prepared speech where debaters delivered their drafted written speech; and, (2) the instantaneous speech where debaters had to answer impromptu questions. As observed, the two subjects would only attempt part 1 and avoid part 2 . In fact this was also observed with the others. Only the good students would dare to attempt part 2 and they would not take long to answer the questions.

Overall, when debating, the two subjects chose to avoid interaction. Never once was there any attempt to ask questions. That is they would only deliver their prepared speech without any verbal exchanges from the opponent except to give the respond "Deny". This was probably due to lack of confidence (affective factor) and or limited linguistic resources (cognitive factor). As stated by Goh (2012), speaking involves social, cognitive as well as affective factors. To avoid embarrassing themselves, the participants chose not to get out of their comfort zone; they abstained interaction. During debate both subjects showed a tendency to use compensation (Oxford, 1990) and avoidance strategies (Færch \& Kasper, 1983). Although more communicative strategies will be used as learners make more attempts to interact (Tarone, 1980), compensation strategy is one of the preferred strategies over others by the participants (Razi, 2012).

Despite the overall improvement made by both subjects, it was noted that the main challenge the boy faced in his delivery was his personality. He needed to overcome his shyness and improve his articulation (poor pronunciation) which affected his message. This was confirmed with his reaction at the first interview. Despite this, he gave a positive response to debate in six months later. This was the opposite with the girl who would not want to debate even though her debate performance was better. As stated by Goh (2012), speaking involves the interplay of cognitive and affective factors. With debate it is more challenging as it involves not only arguments but the participants need to think fast when replying questions posed during POIs. During the debate, unlike the boy, the girl chose to accept POI once during the competition. However, she could not think on the spot to answer the question posed. This could explain her reluctance to participate. Scaffolding should also be provided to prepare student in replying POIs.

During the interview both agreed that the debate script provided was helpful. The debate script is an example of a spoken text of a discourse which helps the leaners to pick the structure involved in a particular discourse, in this case debate (Burns et al., 1990). Through the debate script, students become aware of the language and this can assist them in greater accuracy (Goh, 2007). As they internalize the phases, they become independent of the script at later rounds. According to Cameron (2001), scaffolding should be given in relation to the needs of the learner and should be adjusted as the learner becomes more competent. The subjects also mentioned the advantages of the discussion or brainstorming session. These are actually communicative and collaborative activities that would help learner to be more engaged while listening to their peers (Goh, 2014; Weimer, 2013). As stated by the subjects even though they did not contribute much, they listened carefully to their friends' ideas/contributions during the discussions. They believed the more they know about the subject matter the better they are in giving arguments. This was crucial as they had to prepare their script based on the discussion. Thus, students' content knowledge affects their performance. Lastly, another factor that helped students in developing their oral presentation was the repeated debate activity they had carried out. This is an example of a task-based activity suggested by Skehan (1996). 


\section{Conclusion and Implication}

Although this study was limited to two students, it does contribute to understanding of how students with lower English proficiency level react to debate. This study also showed that debate can be used as a teaching tool and is not limited only to the proficient ESL learners. If sufficient scaffoldings are provided, debate can be a teaching activity for low proficient ESL learners. It allows students to voice their opinion via the prepared speech and/or instantaneous speech when they are ready. To support students to overcome their fear of accepting POIs, teachers need to provide scaffoldings. It is suggested that more time should be allocated to learners during the brainstorming to anticipate opponents' arguments which can help them be mentally prepared. Teachers need to build rapport with students who are shy and encourage them to try to accept POIs. Teachers can do a lot to help students with their articulation. Students need to notice the language particularly the intonation and pronunciation and this is where teachers need to give coaching. Speaking is instantaneous and it is not possible to capture their learning process (Goh, 2014). Thus, the use of recorded videotape can allow learners to notice their speech and be aware of their learning process or weaknesses in their delivery and teachers can use this to help them improve.

\section{Acknowledgements}

We would like to thank all the participants and teachers who took part in this research. The research received the Putra Grant from University Putra Malaysia.

\section{References}

Brice, A. E. (1992). The adolescent pragmatics screening scale: Rationale and Development. Howard Journal of Communications, 3(3), 177-193. http://dx.doi.org/10.1080/10646179209359748

Brown, G., \& Yule, G. (1983). Teaching the spoken language: An approach based on the analysis of conversational English. Cambridge: Cambridge University Press.

Bruer, J. T. (1998). Education. In W. Brechtel, \& G. Graham (Eds.), A companion to cognitive science (pp. 681-690). Massachusetts: Blackwell.

Burns, A., Joyce, H., \& Gollin, S. (1996). 'I see what you mean': Using spoken discourse in the classroom: A handbook for teachers. Sydney: National Centre for English Language Teaching and Research.

Bygate, M. (2001). Speaking. In R. Carter, \& D. Nunan (Eds.), The Cambridge guide to teaching English to speakers of other languages (pp. 14-20). Cambridge: Cambridge University Press. http://dx.doi.org/10. 1017/CBO9780511667206.003

Cameron, L. (2001). Teaching language to young learners. Cambridge: Cambridge University Press. http://dx.doi.org/10.1017/CBO9780511733109

Canale, M., \& Swain, M. (1980). Theoretical bases of communicative approaches to second language teaching and testing. Applied Linguistics, 1(1), 1-47. http://dx.doi.org/10.1093/applin/1.1.1

Chaney, A. L., \& Burk, T. L. (1998). Teaching oral communication in grades K-8. Boston: Allyn \& Bacon.

Creswell, J. W. (2007). Qualitative inquiry and research design: Choosing among five approaches (2nd ed.). Lincoln, NE: Sage Publications.

Edwards, R. (2008). Competitive debate: The official guide. New York: Penguin.

Færch, C., \& Kasper, G. (1983). Communication strategies in interlanguage production. London: Longman.

Freiermuth, M., \& Jarrel, D. (2006). Willingness to communicate: Can online chat help? Journal of Applied Linguistics, 16(2), 189-212. http://dx.doi.org/10.1111/j.1473-4192.2006.00113.x

Goh, C. M. (2014). Reconceptualising second language oracy instruction: Metacognitive engagement and direct teaching in listening and speaking. The Asian Journal of English Language \& Pedagogy, 2, 1-31

Goh, C. M., \& Burns, A. (2012). Teaching speaking: A holistic approach. New York: Cambridge University Press.

Harmer, J. (2001). The practice of English language teaching (3rd ed). London: Longman.

Henzl, V. M. (1979). Foreigner talk in the classroom. International Review of Applied Linguistics, 17(2), 159-167.

Hymes, D. H. (1971). On communicative competence. Philadelphia: In J. B. Pride, \& J. Holmes (Eds.), Sociolinguitics (pp. 269-293). Hammondsworth, UK: Penguin. 
MacIntyre, P. D., Baker, S. C., Clément, R., \& Donovan, L. A. (2003). Talking in order to learn: Willingness to communicate and intensive language programs. The Canadian Modern Language Review, 59(4), 589-607. http://dx.doi.org/10.3138/cmlr.59.4.589

Nolasco, R., \& Arthur, L. (1987). Resource books for teachers: Conversation. Oxford: Oxford University Press.

O’Malley, J. M., \& Chamot, A. U. (1990). Learning Strategies in second language acquisition. Cambridge: Cambridge University Press. http://dx.doi.org/10.1017/CBO9781139524490

Othman, M., Mohamad, F., \& Amiri, F. (2013). An English debate league among lower form students: An experiential learning. US-China Foreign Language, 11(11), 840-852.

Oxford, R. (1990). Language strategies: What every teacher should know. New York: Newbury.

Patton, M. Q. (1985). Quality in qualitative research: Methodological principles and recent developments. Paper presented at the invited address to division $\mathrm{J}$ of the American Educational Research Association, Chicago, IL (April).

Phillips, E. (1992). The effects of language anxiety on student test oral performance. The Modern Language Journal, 76, 14-26. http://dx.doi.org/10.1111/j.1540-4781.1992.tb02573.x

Razi, S. (2012). Turkish EFL learners' language learning strategy employment at university level. Journal of Theory and Practice in Education, 8(1), 94-119.

Skehan, P. (1996). A framework for the implementation of task-based instruction. Applied Linguistics, 17(1), 38-62. http://dx.doi.org/10.1093/applin/17.1.38

Tarone, E. (1980). Communication strategies, foreigner talk and repair in interlanguage. Language Learning, 30, 417-431. http://dx.doi.org/10.1111/j.1467-1770.1980.tb00326.x

Thornbury, S. (2005). How to teach speaking. Essex: Longman.

Ur, P. (1996). Course in language teaching: Practice and theory. Cambridge, MA: Cambridge University Press.

Weimer, M. (2013). Learner-centered teaching: Five key changes to practice. San Francisco: John Wiley \& Sons.

\section{Copyrights}

Copyright for this article is retained by the author(s), with first publication rights granted to the journal.

This is an open-access article distributed under the terms and conditions of the Creative Commons Attribution license (http://creativecommons.org/licenses/by/4.0/). 